\title{
Tax and Accounting Treatment on the Revaluation of Fixed Assets (Land) in Indonesia
}

\author{
Mila A. Reyes \\ mila.reyes@president.ac.id \\ Accounting Study Program, Faculty of Business \\ President University, Cikarang, Indonesia \\ Gita Ghaisani Haniyah \\ gitaghaisani03@yahoo.com \\ Accounting Study Program, Faculty of Business \\ President University, Cikarang, Indonesia
}

\begin{abstract}
Revaluation of assets Property, Plant and Eguipment (PPE) is carried out by a company with the aimed to provide financial statements which are more fair and reasonable. However, the question arise about how is the tax treatment for this asset assessment. The lack of regulations that regulate it makes the author to be motivated to research and hopefully can provide information to taxpayers and give suggestions to the tax authorities regarding how the tax treatment for this asset assessment. This research is using a qualitative approach with data collection through in-depth interview and literature study. The research conclude to eliminate all of the perception regarding the actual tax treatment, the tax regulator must always update or revise the tax regulations with changes or revisions made by the Financial Accounting Standards (SAK). This research is limited only on the discussion of the tax treatment towards revaluation based on the Statement of Financial Accounting Standards (PSAK) 16.
\end{abstract}

Keywords: revaluation, Fixed Asset, Tax Treatment, Statement of Financial Accounting Standards (PSAK) 16, Ministry of Finance Regulation (PMK) No. 79

\begin{abstract}
Abstrak
Revaluasi terhadap tanah dilakukan oleh sebuah perusahaan dengan tujuan untuk menyajikan laporan keuangan agar terlihat lebih adil dan masuk akal. Atas kegiatan tersebut muncul sebuah pro dan kontra mengenai bagaimana seharusnya perlakuan pajak atas kegiatan tersebut. Adanya kekosongan peraturan yang membahas hal tersebut membuat peneliti terdorong untuk memberikan pengetahuan kepada wajib pajak dan saran kepada otoritas pajak mengenai bagiamana sebaiknya perlakuan pajak atas kegiatan tersebut. Penelitian ini menggunakan pendekatan kualitatif dengan teknik pengumpulan data melalui wawancara mendalam dan studi kepustakaan. Berdasarkan hasil penelitian, untuk meghilangkan pro dan kontra yang ada maka regulator pajak harus selalu berusaha untuk melakukan pembaruan atau merevisi peraturan perpajakan dengan perubahan atau revisi yang dilakukan oleh Standar Akuntansi Keungan (SAK). Penelitian kali ini terbatas hanya membahas perlakuan pajak terhadap revaluasi yang dilakukan berdasarkan Pernyataan Standar Akuntansi Keuangan (PSAK) 16.
\end{abstract}

Kata Kunci:

revaluasi, asset tetap , perlakuan perpajakan, Pernyataan Standar Akuntansi Keuangan (PSAK) 16, Peraturan Menteri Keuangan (PMK) No. 79 


\section{INTRODUCTION}

Accounting and Taxation are two aspects that a company will always need. Accounting aspects present information about circumstances that occur during a certain period to management or other interested parties in order to assess the financial condition and performance of the company. On the other hand, taxation aspects specifically present financial reports and other information to the tax administration. Taxation aspects are based on the tax laws applied in Indonesia and implemented by the government. The aim is to determine the amount of tax payable based on financial statements prepared by the company, meanwile, accounting aspects are prepared and presented based on Indonesian Statement of Financial Accounting Standards (in Bahasa, Pernyataan Standar Akuntansi Keuangan or PSAK).

For tax purposes, accounting aspects must be adjusted to the tax rules applied in Indonesia. Thus, if there is a difference between the accounting provisions and the tax provisions, then for the purpose of calculation, tax payments and reporting, the tax provisions always prevail. Although the accounting standard is commonly applied from the idea for tax assessment, there are reasons why there ought to be difference between the figures used for accounting and for tax assessment. Related to the differences between the accounting aspects and the taxation aspects, in this study the author will focus on differences in accounting and taxation aspects that occur for fixed assets (land) revaluation cases. Revaluation of fixed assets value in a company is done due to an increase in the value of the fixed assets in the market or due to the low valuation of fixed assets in the company's financial statements caused by devaluation or others, that the value of fixed assets in the financial statements no longer reflects the reasonable or the fair value (Waluyo, 2011). Accounting requirements for fixed assets addressed in Indonesia is in Statement of Financial Accounting Standards (PSAK) 16, Property, Plant, and Equipment.

Revaluation, based on PSAK 16 revised in 2011 Paragraph 29 states that the entity can opt between the cost model in paragraph 30 or the revaluation model in paragraph 31 as its accounting policy and apply that policy to all fixed assets within the same group. Paragraph 30 states that after being recognized as an asset, fixed assets are recorded at cost less accumulated depreciation and accumulated impairment losses on assets. Paragraph 31 states that after being recognized as an asset, fixed assets whose fair value can be measured reliably must be recorded with the revaluation value, namely the fair price at the date of revaluation less with accumulated depreciation and accumulated impairment losses that occur on the date of revaluation. From the description above, it may be interpreted that the entity may measure assets after initial recognition by conducting a consistent revaluation model for all fixed assets in the same group. The grouping of assets exemplified in accordance with Paragraph 37 consist of land, land and buildings, machinery, ships, aircraft, motor vehicles, furniture and office equipment. Basically, companies do fixed assets revaluation to provide a fair image of its financial position and performance.

In contrast to PSAK, according to the prevailing tax regulations, namely the Ministry of Finance Regulation (PMK) No.79/PMK.03/2008 in general, the revaluation of fixed assets is regulated as follows: "The company can revalue the company's fixed assets for tax purposes, provided that it fulfills all of its tax liabilities until the last tax period before the tax period is carried out for the revaluation." To conduct a revaluation of the company's fixed assets, the company must submit an application to the Director General of Taxes (DGT). DGT is authorized to issue a decree on fixed assets revaluation on an application submitted by the company. Assessment of the company's fixed assets is implemented on: 
a. All tangible fixed assets, including land with rights of ownership or rights of use; or

b. All tangible fixed assets do not include land, located at Indonesia, owned, and used for acquiring, accumulating and continuing to have income which is the tax object. The difference over the revaluation of the company's fixed assets above the original fiscal book value is subject to final income tax of $10 \%$ (ten percent).

According to the PMK 79, the revaluation regulated is the revaluation done only for taxation purposes. Before doing the revaluation the company must get an approval first from the Director General of Taxes (DGT). When approved, the difference or additional value as a result of the revaluation, will be subject to a final income tax of $10 \%$.

Based on the explanation above, we can conclude that the revaluation of fixed assets for accounting and for taxation has a different purpose. For accounting which follows the provisions of PSAK 16, revaluation of assets aims only to present the value of assets that are appropriate or close to their fair values intended to present fair financial statements. Whereas, the revaluation of assets for taxation is carried out due to certain reasons or conditions (ex: changes in exchange rates) where the goals is to increase the value of assets and then present it in an appropriate or close to their fair value which later can provide benefits for taxation purposes.

Related to the explanation above, if the company decides to revalue its fixed assets (land) with the aim of presenting a more reasonable or fair financial position in accordance with PSAK 16, then the revaluation also must be presented in the financial statements reported. The problem arise when companies got tax audit instruction letter or in other word the company will be audited by the tax authorities. The tax authorities will soon find out that there is an increase in value of fixed asset (land) and considered it as subject to final income tax of $10 \%$ based on PMK No.79/PMK.03/2008. It will be subject to final income tax because tax authorities considered that the company get benefits from fixed asset (land) revaluation.

Taxpayer certainly will not agree if the increase in value of fixed asset (land) from that revaluation is taxed. There are several arguments according to the Taxpayer about the revaluation above, in which it should not be taxed. First, the absence of taxation regulation about revaluation of fixed asset (PMK No.79/PMK.03/2008) for accounting purposes. Second, based on Law of General Provisions and Tax Procedures Article 28 there is explanation about paragraph 7 that stated tax must follow accounting (PSAK 16), if tax does not regulate it. Third, land is non-depreciable assets which at the end do not have a direct influence on the calculation of tax, so it is not to be challenge or to be imposed by a final income tax of $10 \%$ by tax authorities in the future.

The contra side or the challenge comes because of the tax authorities. Their attitudes and thoughts make them not dare to take risks to make different decisions. They always tend to make decisions based on applicable written regulations. Therefore, the revaluation of fixed asset (land) is still taxed by final income tax of $10 \%$ on the difference or additional value of fixed asset (land), which, in effect, is very detrimental to the company.

\section{LITERATURE REVIEW}

\section{Revaluation Concept}

Revaluation is taken from the word re- and valuation (value), where re- means repetition or return while valuations derived from the word value so that valuation can be interpreted as an assessment or valuation process. So the word meaning of revaluation itself is a reassessment. The valuation process is a systematic procedure carried out in order to obtain answers to company or client questions about the value of a real property. This theory was 
introduced by Alfred Marshall cited from the Appraisal Code of Ethics Module and Indonesian Assessment Standards. Marshall introduces three traditional valuation approaches, namely market (sales) comparison, replacement cost, and revenue capitalization. Furthermore Irving Fisher developed the income theory of value which is the basis of the income capitalization method used in modern valuations.

In Indonesia, based on the Appraisal Ethics Module and the Indonesian Assessment Standards there are three traditional approaches to assessing. These three revenues are explained by Harahap (1994), the following is an explanation of each approach:

a. The Sales Comparison/Market Approach is a method of valuation where estimated market value based on the value that occurred at the time of the transaction.

b. Cost Approach is a system of valuation where the cost of the assets is obtained from new reproduction costs less depreciation.

c. Income Capitalization is a method of valuation wherein the net profit is analyze

to get the amount of investment in producing the profit.

The conclusions from the results of the valuation can be in the form of a single value or range value where it depends on the effective integration of all elements in the assessment process depending on the appraiser's expertise, experience, and income/consideration. In the implementation of the revaluation, sometimes only the asset book value is changed, but often in addition to the book value of the asset, the asset life will also be adjusted. Revaluation can be recorded or not recorded in the account, only the book value is corrected to match the percentage of circumstances determined from the revaluation.

Revaluation provides advantages and disadvantages for the company. Advantages are as follows:

1. The balance sheet will show a reasonable position of the net worth, so the users of financial statements can obtain more accurate and precise information.

2. The difference in revaluation will also increase its own capital structure, which means that the ratio of loans with equity or Debt to Equity Ratio (DER) improves.

3. With the improvement of DER, companies can withdraw funds through loans from third parties or share issuance.

Meanhile, the disadvantages of the revaluation are:

1. The increase in depreciation expense is charged to profit or loss or charged to cost of goods sold.

2. In terms of taxation, the difference resulting from the revaluation is a tax object to final income tax.

With the various advantages and disadvantages caused by the revaluation, the management of the company must consider carefully when deciding to revalue fixed assets in the future (Hutagaol, 2007).

\section{Revaluation of Fixed Assets According to Accounting}

Under PSAK No.16 fixed assets are tangible assets acquired in the form of either readyto-use or built in advance, used in the company's business activities, not intended to be sold in during the normal business operation and have a useful life of more than one year, except in certain conditions for example, assets owned are damaged and can be sold. In their book, Kieso, Weygandt, and Warfield (2018) use the term plant assets in interpreting fixed assets. According to them, fixed assets are assets which have three features:, namely having physical existence (a definite measure of size and shape), used for the company's business activities and not intended for sale. Fixed assets are usually long-term and are used to generate services for companies for several years. Warren, Reeve, and Fess (2006) also stated that fixed assets are long-term assets or are relatively permanent assets. Fixed assets are also referred to as 
tangible assets because of their physical form. Other description of these assets are plant assets or property, plant, and equipment.

\section{Classification of Fixed Assets}

Fixed assets in a company can vary in shape, therefore there are classification of fixed assets. Broadly speaking, the classification of fixed assets is divided into two, namely:

\section{Tangible Fixed Assets}

Tangible fixed assets are assets which are permanent nature and can be used for a relatively long period of time. These tangible fixed assets are still subdivided into three, namely:

a. Fixed assets with specified number of years and when they are expired it can be substituted with identical assets, for example: equipment, machinery, vehicles, buildings, and others.

b. Fixed assets with specified number of years and when they are expired it cannot be substituted with identical assets, for example: natural resources such as mining, forest, and others.

c. Fixed assets whose age is not limited, for example: land for location companies, agriculture and livestock.

\section{Intangible Fixed Assets}

Intangible assets are non-monetary assets which are without physical substance and identifiable (either being separable or arising from contractual or other legal rights. Intangible assets meeting the relevant recognitioncriterial are initially measured at cost, subsequently measure at cost or using the revaluation model and amortizedon a systematic basisover their useful lives (unless the asset has an indefinite useful life, in which it is not amortized). (International Accounting Standards, 2009).

\section{Recognition of Fixed Assets}

Fixed assets can be obtained in various ways. According to Kieso, Weygandt, and Warfield (2018) the acquisition price is a cost that consists of the total expenditure incurred to get assets and make it ready for use. After the acquisition price is determined, the amount is used as the accounting basis for the fixed assets over the useful life. Baridwan (1995) also said the same thing, to determine the acquisition price of asset all cost incurred from the purchase until the asset is ready for use must be capitalized. Types of assets can be vary, each type has a different way of determining the amount of the acquisition price.

Under PSAK 16 (revised 2011) acquisition cost is the amount of cash or cash equivalents paid to obtain an asset. Accordingly, fixed assets must be recognized as an asset if and only if: (a) most likely the entity will obtain future economic benefits from the asset; and (b) the cost of assets can be measured reliably.

After initial recognition, an entity can choose from either cost model or revaluation model as its accounting policy and apply the policy to all fixed assets in the same group. Under the Cost Model, after being recognized as an asset, a fixed asset is recorded at cost less accumulated depreciation and accumulated impairment losses on asset value, while under the Revaluation Model, after being recognized as an asset, a fixed asset whose fair value can be measured reliably must be recorded at the revalued amount.

Initially in PSAK 16 (1994) an entity is only permitted to use the cost model and is not permitted to use the revaluation model. Therefore there is no further description of the revaluation of fixed assets. However, in the PSAK 1994 there are exceptions, namely an entity is permitted to revalue fixed assets as long as the revaluation is carried out by 
following government regulations. In this case the relevant government regulations are regulations in the field of taxation. In 2007 PSAK was revised, one of which was in terms of measurement after initial recognition. In PSAK 16 (2007), it is stated that an entity can opt to either the cost model or the revaluation model as an entity's accounting policy and apply the policy to all fixed assets in the same group. If an entity uses the cost model, the fixed asset is recorded at cost less accumulated depreciation and accumulated impairment losses on assets. This cost model is the same as the previous accounting standard.

There is a reason why PSAK (2007) allows companies to opt between the cost model and the revaluation model as their accounting basis. The new regulation was originally adapted from IFRS. Presently, there are old companies that cannot compete with new companies judging from the value of their assets because they use the acquisition value as their basis for recording. Therefore, with the new regulation, PSAK provides an option for companies to be able to compete fairly with each other by deciding whether they will be using the cost model or revaluation model as their accounting basis, however, the most important thing is that they have to use the method they opted consistently.

\section{Depreciation of Fixed Assets}

Asset continue to have an inherently susceptible nature to impairment in line with their use or utilization. Therefore, companies must adequately relay reliable data concerning the value of fixed assets so that they can be used fairly to make decisions. The definition of depreciation of fixed assets according to Kieso, Weygandt, and Kimmel (2018) is the method of apportioning value of plant asset over its useful (service) life in a logical and orderly manner. According to PSAK 16 (revised 2011) depreciation is a systematic allocation of the amount that can be depreciated from an asset over its useful life.

In the implementation of depreciation of fixed assets by the company, there are several factors that affect the amount of depreciation. These factors include Cost of Goods (the amount that must be spent to obtain a fixed asset), Residual Value (estimated value of the realization of the fixed asset after the end of its use or when the fixed asset must be withdrawn from production activities), useful life (estimated time period the use of fixed assets in production activities, and the method of record the depreciation.

\section{Revaluation of Fixed Assets}

Revaluation of fixed assets is the reassessment of the company's fixed assets to reflect the current market value of the assets or because of the low of value in the financial statements caused by devaluation or other causes. In PSAK No. 16 , it is the recognition of an asset, property, plant and equipment where fair value can be reliably measured, are recorded at the revalued amount, which is the fair value at the date of revaluation less accumulated depreciation and accumulated impairment losses that occur after the revaluation date. Revaluation must be carried out regularly to ensure that the carrying amount does not differ significantly from its fair value. The standard does not specify how many years, revaluation is carried out but depending on the volatility of the fair value of fixed assets. If the price does not change significantly, perhaps a revaluation can be done every three or five years, but if the significant price changes, the revaluation is possible in every year. The fair value of land and building is usually set on through an assessment carried out by assessors who have professional qualifications. The fair value of the plant and equipment usually uses the market value decided upon by the professional appraiser.

To present a fixed asset revaluation, if the value of the fixed assets becomes higher due to the assessment, increase in value is recognized as other comprehensive income (OCI) and is accumulaed in the equity section as revaluation surplus. However, the increase must be recognized in the income statement up to the amount of the asset impairment of the same 
fixed asset as a result of previously recognized revaluation in profit and loss. If the value of the fixed asset decreases due to revaluation, the decrease in value is recognized in the other comprehensive income (OCI) as long as it does not exceed the surplus balance of carrying asset. A decrease is recognized in the income statement if there is no revaluation surplus balance due to the revaluation of previous periods. The revaluation surplus that is in equity can be transferred directly to retained earnings when the asset is discontinued, or the transfer can also be made in parallel with the use of the asset by the entity (partially realized). The amount transferred is the difference between revaluation and depreciation and cost, (or the revaluation surplus value divided by the remaining economic useful lives

Assets that can be revalued are tangible assets in the form of land, groups of buildings, and not buildings that are not intended to be transferred or sold. Based on PSAK 16 Paragraph 36, if an asset is revalued so all fixed assets in the same asset group must be revalued. A group of fixed assets is a grouping of assets that have similar nature and utilization in the normal operation of the entity. An asset in a group of fixed assets must be revalued simultaneously to avoid selective revaluation and mix of acquisition costs and other values. However, a group of assets can be revalued alternately (Rolling basis) as long as the revaluation of the group of assets can be completed on time. Based on Paragraph 37 the example of a group of assets that can be revalued are: machinery, ship, aircraft, motor vehicle, office equipment, furniture, land and building, and land.

Land that is intended to be revalued based on PSAK 47 Paragraph 7 is a tangible fixed asset acquired in ready-to-use or acquired and then perfected to be ready for use in the entity's operational activities with economic benefits of more than a year, and are not intended to be traded in the entity's normal operations. In general, land assets are not depreciated, but only in some special conditions, land can be depreciated. The special conditions referred to PSAK 47 paragraph 17 are as follows:

a. The condition of land quality is no longer suitable for use in the main operations of the entity.

b. The nature of the main operation just leaves the land and building if the project is completed. Example is land and building in remote areas. In this case the land is depreciated according to the estimated length of the main operating schedule or the project.

c. Management predictions or certainty that the extension or renewal of rights is most likely or uncertain.

\section{Revaluation of Fixed Assets According to Taxation}

Before discussing further about the revaluation of fixed assets based on taxation, first we must know the concept of the tax itself. According to Djajadiningrat (2003) tax is a commitment to allocate a part of one's riches to the state treasury due to a circumstance, occurrence and action that gives a particular position, but not as a sanction, according to the ruling that can be enforced by the government, but there is no corresponding favor from the state directly, which aims to continue and keep the well-being in general. Saputra (2005) also states that in business world, taxes are a source of expenditure without them getting the direct benefits. Based on the explanation above, in terms of paying taxes, the company will usually try to make the tax expenditure as small as possible through tax planning. The aim is to streamline the amount of tax owed through tax avoidance without having to violate the tax laws. One example of tax planning that is relevant of today's business is through a revaluation of fixed asset the policy refers to the Ministry of Finance Regulation No. 79 of 2008 regarding Revaluation of Company Fixed Assets for Taxation Purposes.

As discussed in the previous paragraph, based on taxation regulation in Indonesia, revaluing of fixed assets for tax purpose is regulated in the Ministry of Finance Regulation 
Number 79/PMK.03/2008. The Minister of Finance has its own considerations and reasons why they passed a regulation for the revaluation of fixed assets. There is a striking price development or a change in monetary policy that can cause a mismatched between costincome harmony which eventually may lead to an unreasonable tax burden, so, finally the regulation was created because of that consideration.

The concept and the definition of revaluation in taxation is actually not different with the concept and the definition of revaluation in accounting. However, there are several points discussed differently in this PMK 79, such as, who can do the revaluation, what are the objects that may be revalued, what procedures should be carried out to do the revaluation, how many times the revaluation can be carried out, what are the requirements that must be fulfilled for doing the revaluation, and any other points that will be discussed in the next few paragraphs.

PMK No.79/PMK.03/2008 Article 1, states that tax subjects or taxpayers who can revalue their fixed assets, namely domestic corporate taxpayers and Permanent Establishments (PE), hereinafter referred to as companies, may conduct revaluation of fixed assets for tax purposes, with the provision that it has fulfilled all its tax obligations up to the last tax period before the tax period is revalued. Domestic corporate taxpayers and Permanent Establishments (PE) do not include taxpayers who have permission to hold bookkeeping in English and US Dollar.

In revaluing the company's fixed assets, based on PMK No.79/PMK.03/2008 Article 2, companies must submit an application first to the Director General of Taxes, which is the authorized party that issue a decree on the revaluation of the company's fixed assets on the submitted application by the company. After obtaining a decree stating that it is permissible for a company to implement assessment procedure, then the revaluation can be carried out by license appraiser. The assessment of the value company's fixed assets must be based on the market value or the fair value of the fixed assets when the assessment is carried out, which is determined by the appraisal service company or appraisal experts that obtains a permit from the Government. If the market value or fair value determined by the appraisal service company or appraisal experts does not reflect the actual conditions, then the Director General of Taxes can reassign the market value or fair value of the relevant fixed assets. PMK No.79/PMK.03/2008 Article 4 Paragraph 3 regulated that revaluation of fixed assets is carried out within a maximum period of 1 year from the report date of the appraisal service company or appraisal experts.

PMK No. 79 of 2008 dated May 28, Article 3 Paragraph 1, states the fixed assets of the company that can be revalued, namely:

a. All tangible fixed assets, including land with ownership or use rights; or

b. All tangible fixed assets excluding land, which are located in Indonesia, owned and are utilized to acquire, accumulate, and affirm income which is the object of tax.

Based on the Ministry of Finance Regulation, the revaluation of the company's fixed assets can be carried out again five year after the last revaluation.

For the revaluation difference that exceeds the remaining value of the fiscal book based on the provisions of Article 5 PMK No.79/PMK.03/2008, it is subject to final Income Tax of 10\%. Meanwhile, based on the Ministry of Finance Regulation No.191/PMK.010/2015 there is special treatment regarding tax rates that are given for the applications that are requested in 2015 and 2016. There are discount of tax rates that are given by the Minister of Finance, 3\% of rates for applications that submitted since the PMK 191 apply to December $312015,4 \%$ of rates for applications that submitted from 1 January 2016 to 30 June 2016, and 6\% of rate for applications that submitted from 1 July 2016 to 31 December 2016. The revaluation difference that exceeds the commercial book value after deducting with the income tax must 
be presented in the commercial Statement of Financial Position at the estimated capital under account name "Excess of revaluation of taxpayer's fixed asset at the date of ...".

As explained in the previous paragraphs, there is no limit on what fixed assets that can be revalued, so land especially in the aspect of taxation can also be revalued just like any other fixed asset. One thing that needs to remember if land wants to be revalued for taxation purposes, then it must follow all the requirements and procedures that have been explained and regulated in PMK No.79/PMK.03/2008.

\section{Research Objective}

Every research has purpose and objective. The main objective of this research is to find out whether companies that have revalued land assets for accounting purposes must be subject to final income tax of $10 \%$ or not. In addition, the writer aims to provide information and awarenes to the government about the current problem in accounting and tax regarding the treatment of the revaluation of fixed asset (land) which currently are not in harmony based on the existing regulations in PSAK and regulations in PMK so that they will update these regulations in order not to confuse the public. This also aim to increase taxpayer's knowledge about taxation issues regarding the tax treatment on revaluation of fixed assets based on PSAK16.

\section{RESEARCH METHOD}

There are two types of research approaches, namely qualitative and quantitative approaches (Creswell, 1994). This research begins with looking at social phenomena and then understanding them by forming a holistic and intricate picture, and exhibit it with words. Therefore, a qualitative approach is used, so that researcher can find deep understanding and interpretation. According to Chilisa (2011) a qualitative method is a research method based on the principles of post-positivism, utilized to investigate the state of true nature of objects where the researcher is a key instrument. Based on the understanding of a qualitative approach from Creswell (1994) a qualitative approach is a process of inquiry to comprehend social or human dilemma by developing an inticate and complete picture, described by words, accounting detailed information from the perception of the respondents, and implemented in a normal setting. According to Maanen (1979) in Cooper \& Schindler (2008) defines qualitative research as a series of interpretive techniques that seek to describe, decode, and translate all the information that already gather from the social settings.

From the above explanation, we can conclude that a qualitative approach is a scientific study done to know thoroughly social or human intricate unsettled questions by moulding a detailed and intricate image exhibited in words, describing the complete perception derived from sources of information, and executed in a natural setting. In a different book, Creswell added that qualitative research starts with assumptions, world phenomena, and problem studies from individuals or groups related to social or human problems. Furthermore, according to Creswell, there are five types of qualitative research, namely, biography, grounded theory study, case studies, phenomenology and ethnography.

In the process of qualitative research there are activities or procedures that must be done by the researcher, including asking questions, collecting specific data from participants, analyzing data inductively starting from topics that are specific to common topics and interpret the meaning of the data (Creswell, 2013).

Data analysis is one of the important procedure in research method. The benefit of doing the data analysis is it can give a meaning to the data being analyzed, so it has function to solve research problems. Data analysis can be done after all of data is collected. 
This research is included in the category of pure research or in bahasa Indonesia is called penelitian murni. According to Neuman (2007), pure research or penelitian murni is a basic research or academic research with explanation that basic researcher focus on supporting theories that explain how the social world operates, what makes things happen, why social relationships are formed, and why society changes. Pure research or penelitian murni could be defined as a research of something because its curiosity as a results from an activity or social phenomenon. The results from pure research or penelitian murni could be in the form of general knowledge and understanding the laws. That general knowledge could be used as a tool to solve the practical problems, even though cannot give the answer directly to every problem.

If we look from the research purpose, then this research is included in the type of descriptive research. Descriptive research is a research that tries to describe phenomenon or social symptoms, present a complete picture regarding social settings and relationships that exist in a research. The phenomenon that will be described in this research is about imposition of final tax of $10 \%$ against revaluation of land, which the aim of the revaluation itself is to make the financial report looks more reasonable or fair (purpose accounting), not for taxation purpose.

Neuman (2007) explains that descriptive research is an illustration of particular details of a circumstances, sociocultural, or connections; it focuses on "how" and "who" questions. He thinks that a many of social studies is descriptive. Descriptive researcher do great deal of data collection methods such as surveys, field research, content analysis and historical comparative research.

If we look from the dimensions of time, this research is included in cross-sectional study, Neuman (2007) argues that a cross-sectional study is a research that conduct with only look in one points of time event or take approach in one image of an event and do the detail analysis on that event.

This research is conducted in one time. This research only used a certain time and will not be doing another study at a different time for comparison. One thing that must be remembered is that the understanding of one time is not only limited on count of week, a month or a year only.

Primary data is obtained directly from respondent that is related with the problem research, it called field research. Field research is done through a deep interview with the respondent. For secondary data it is obtained by learning various literature such as books, journals, and articles related with this research, it called literature studies (Hadi, 2005).

The literature study conducted in this study is by reading and collecting data derived from literature such as books, journals, papers, articles, magazines, and newspapers in the form of hardcopy or softcopy. In addition, researcher also use laws and other government regulations as the data used in the writing of this study.

In this study, researcher will use literature study and interview as an instrument in collecting the data. Researcher will analyze data from interviews, literature studies and legal documentation related to asset revaluation, especially land according to accounting and taxation. The next step, the researcher will process the data obtained, so the researcher can get an overview of the problem. The researcher will then do a triangulate information, namely the check and recheck process between one source and other data sources. Researcher will also look for the meaning of each data that has been reviewed until later linked to the research problems. 


\section{DATA ANALYSIS AND DISCUSSION}

\section{Analysis of Differences in Asset Revaluation According to Accounting and Taxation}

Reviewing current developments, there are no official adjustments for these two regulations (PSAK 16 and PMK 79) so, the treatment of revaluation of fixed assets according to taxation and accounting still contain some substantial differences. On the other side, PMK accommodates the annual tax revenue target and uplift the national economy massively, while on the other hand, PSAK 16 provides a choice of after recognition measurement models, which one of them is a revaluation model with a background to provide financial statement reporting is more relevant and useful for decision-making. This means that there are two different rules with different backgrounds. PMK No.79/PMK.03/2008 issued by the Ministry of Finance of the Republic of Indonesia, whereas PSAK 16 is the official financial accounting standard in Indonesia that uses IAS 16 - Property, Plant and Equipment as the main reference and issued by the DSAK (Dewan Standar Akuntansi Keuangan) of the Indonesian Accountants Association.

From that two regulations, there are at least eight significant differences, including the following:

Table 1. Difference Between PMK 79-Taxation and PSAK 16-Accounting

\begin{tabular}{|c|c|c|c|}
\hline No. & Aspect & PMK 79 - Taxation & PSAK 16 - Accounting \\
\hline 1 & Revalued assets & $\begin{array}{l}\text { Can be done for all or part of } \\
\text { fixed assets. }\end{array}$ & $\begin{array}{l}\text { Must be done with the same } \\
\text { group of fixed assets. }\end{array}$ \\
\hline 2 & $\begin{array}{l}\text { Revaluation } \\
\text { frequency }\end{array}$ & $\begin{array}{l}\text { Revaluation can be done } \\
\text { again after } 5 \text { years from the } \\
\text { previous assessment. }\end{array}$ & $\begin{array}{l}\text { If the fair value of a revalued } \\
\text { asset is materially different } \\
\text { from the carrying amount, it } \\
\text { can be revalued again. }\end{array}$ \\
\hline 3 & $\begin{array}{l}\text { The results of the } \\
\text { appraisal's } \\
\text { evaluation do not } \\
\text { reflect the actual } \\
\text { situation }\end{array}$ & $\begin{array}{l}\text { The Directorate General of } \\
\text { Taxes can reassign the market } \\
\text { value or assets concerned. }\end{array}$ & $\begin{array}{l}\text { Not regulated, using the } \\
\text { market value of appraisal } \\
\text { results only. }\end{array}$ \\
\hline 4 & $\begin{array}{l}\text { The useful life of the } \\
\text { asset after } \\
\text { revaluation }\end{array}$ & $\begin{array}{l}\text { Back to full benefit period in } \\
\text { accordance with the taxation } \\
\text { group. }\end{array}$ & $\begin{array}{l}\text { Applicable prospectively, } \\
\text { depreciated based on the } \\
\text { remaining benefit of the asset. }\end{array}$ \\
\hline 5 & $\begin{array}{l}\text { Consequences for } \\
\text { the sale of fixed } \\
\text { assets that have been } \\
\text { revalued }\end{array}$ & $\begin{array}{l}\text { If the fixed asset is sold } \\
\text { within } 10 \text { years after the } \\
\text { revaluation is carried out, } \\
\text { then revaluation surplus of } \\
\text { the related asset will be } \\
\text { subject to additional final } \\
\text { income tax with the highest } \\
\text { rate applicable at the time that } \\
\text { the revaluation is carried out } \\
\text { minus } 10 \% \text { - assets of groups } \\
3,4 \text {, land, buildings. }\end{array}$ & $\begin{array}{l}\text { If an asset is sold, then the } \\
\text { revaluation surplus on the } \\
\text { asset is transferred to the } \\
\text { retained earnings balance, not } \\
\text { in other comprehensive } \\
\text { income (OCI). For sales, there } \\
\text { is no special treatment, profit } \\
\text { / loss on fixed asset sales } \\
\text { compared the book value of } \\
\text { the revaluation results with } \\
\text { sales proceeds. }\end{array}$ \\
\hline
\end{tabular}




\begin{tabular}{|c|c|c|c|}
\hline 6 & $\begin{array}{l}\text { Account name for } \\
\text { revaluation surplus } \\
\text { on the balance sheet }\end{array}$ & $\begin{array}{l}\text { Presented as "Excess of } \\
\text { revaluation of taxpayer's } \\
\text { fixed asset at the date of ...". }\end{array}$ & $\begin{array}{l}\text { Not specifically regulated, but } \\
\text { implicitly stated a revaluation } \\
\text { surplus. }\end{array}$ \\
\hline 7 & $\begin{array}{l}\text { Revaluation deficit } \\
\text { (revaluation result < } \\
\text { balance sheet value) }\end{array}$ & $\begin{array}{l}\text { Not explicitly regulated. The } \\
\text { concept of thinking is more } \\
\text { about a revaluation surplus, } \\
\text { but it is still regulated if there } \\
\text { is an overpayment of the final } \\
\text { income tax (based on the } \\
\text { initial request vs. the real } \\
\text { result of appraisal), then the } \\
\text { excess is not tax payable } \\
\text { (PMK 191). }\end{array}$ & $\begin{array}{l}\text { Revaluation deficit is } \\
\text { recognized in profit and loss. } \\
\text { However, if previously there } \\
\text { was a revaluation surplus } \\
\text { balance in the OCI, then the } \\
\text { deficit will net-off the surplus } \\
\text { up to the amount that reported } \\
\text { in OCI. }\end{array}$ \\
\hline 8 & $\begin{array}{l}\text { Capitalizationof } \\
\text { revaluation surplus }\end{array}$ & $\begin{array}{l}\text { Can be capitalized into bonus } \\
\text { shares and not being tax } \\
\text { object. But, if the fiscal } \\
\text { surplus is more than } \\
\text { commercial surplus, then it } \\
\text { can be capitalized only up to } \\
\text { the commercial surplus. }\end{array}$ & $\begin{array}{l}\text { Recognized as an OCI, but if } \\
\text { a revaluation deficit has been } \\
\text { presented in the previous } \\
\text { profit and loss statement, then } \\
\text { the surplus will recognize in } \\
\text { profit and loss up to the } \\
\text { amount of the deficit. }\end{array}$ \\
\hline
\end{tabular}

\section{Problem Analysis}

PT X revalued its fixed asset (land) to increase the value of the net worth that is negative (accounting purposes).When the tax authorities audited the company, they found that there is land revaluation and there was no tax payment for that asset assessment carried out by the company. At the end, the revaluation of land will be challenged by the tax authorities by imposing a $10 \%$ tax. This imposition of $10 \%$ tax on revaluation of land with the purpose of accounting, makes the taxpayer feel unfair and continue to uphold with the stance that this fixed asset (land) revaluation amount should not be taxed. The arguments and reasons that made the taxpayer continue to challenge the imposition of $10 \%$ tax is: first, in their tax regulations, PMK No.79/PMK.03/2008, there is an absence of written regulations that discuss and regulate clearly about the revaluation of fixed assets for accounting purposes. The absence or lack of such regulation on this matter make it difficult for the taxpayer to accept the imposition of $10 \%$ tax, and there has been no update for regulation on PMK 79 of 2008 concerning revaluation of fixed assets for accounting purposes, while PSAK 16 itself has undergone regulatory updates by adopting IFRS as a reference for the changes or the updates in 2011, which allows entities to use the revaluation model. Indeed, in 2015 there was an update of this PMK 79 namely PMK No.191/PMK.010/2015, but in the update it only discussed about the revaluation of fixed assets for tax purposes for the applications submitted in 2015 and 2016 only, by providing special or discount rates for taxpayers who revalued their fixed asset for tax purposes in that year. Regarding the revaluation of fixed assets for accounting purposes until now there are no regulations related on how the tax treatment for fixed asset (land) and is still not clearly discussed.

Second, in the explanation of Article 28 Paragraph 7 of the Law on General Provisions and Tax Procedures, there is a statement which states that imposition of taxes must follow the tax rules prevailing in Indonesia, such as, those that are based on the Financial Accounting Standards Regulations (Peraturan Standar Akuntasi Keuangan or PSAK), unless the tax regulation determines differently. Based on this explanation, it can be concluded that if the taxation or PMK does not regulate it, then tax must follow the applicable accounting 
rules or namely, PSAK. So, if the company wants to do a revaluation for accounting purposes it is permissible and the possibility of not being taxed may occur due to the absence of written regulations that discuss about it and there is also no regulation that states that a revaluation with that purpose will be taxed.

Third, regarding fixed assets that are revalued, fixed assets are divided into two, namely, depreciable fixed assets and non-depreciable fixed assets. When doing a revaluation for the purpose of accounting on a depreciable asset, even though there are no written regulations governing it, there is a possibility of being taxed on this activity. This can happen because the depreciation for these assets will later affect the high expense and later will make the company's income and tax are lower. Even though it is not the real purpose when the company did the revaluation, but the tax authorities might still consider it as a tax benefit enjoyed by the company in terms of taxation. So the possibility of imposition of taxes on revaluation of depreciable fixed assets may occur. Whereas, if there is a revaluation of nondepreciable assets, there is no possibility of being taxed. This can happen because there is no depreciation on this asset, so the asset does not affect the profit and loss and there are no tax benefits enjoyed by the company. So, it is safer to revalue non-depreciable fixed assets, such as land, because it has the potential to not incur additional taxes later.

The three considerations above are the reasons and arguments of why the company finally would convinced to revalue the land for accounting purposes only, that is to make the negative net worth of the company positive in order to have a good presentation of the financial postion at year end. But it turns out that the revaluation is still challenged by the tax authorities by imposing a final income tax of $10 \%$. This can happen because the tax authorities is being supervised both internally and externally, so they cannot make their own decision and always followed the existing tax regulation. This attitude and thought of the tax authorities about anything that can increase the state revenues through taxes it must be taxed is also a reason why the tax authorities imposed $10 \%$ tax on fixed asset (land) revaluation. This behavior, attitude and thought are the reason why the tax authorities suddenly challenged the revaluation of land carried out by the company. It can happen because the tax authorities assumed that there is a tax benefit enjoyed by the company from the increase in the value of the land. These attitudes and thoughts are inevitable. The tax authorities itself do not want to take risks by not imposing a final income tax on the revaluation that are considered to have tax benefits enjoyed by the company, because their career is at stake later. Therefore, they prefer to follow the existing written regulations a final income tax on this activity rather than when their supervisors find out that the activities should be taxed but not taxed and eventually become a problem for the tax authorities themselves.

The three considerations that was explained earlier are arguments or statements that are very strong for the company to stick with the conclusion that the revaluation of fixed asset (land) should not be taxed. If we take a look from the company's purposes to revaluing the land, we can see a difference in the purposes, where the company revalue land solely to make the financial statements look good and not negative, not for taxation purposes. Whereas in the tax regulations, it is clearly stated from the existing regulation or PMK that the revaluation of fixed assets are for taxation purposes only, not for accounting purposes. As written in PMK 79 Article 1 paragraph 1:

"The company can revalue the company's fixed assets for tax purposes, provided that it has fulfilled all of its tax obligations up to the last tax period before the tax period is revalued."

Thus, the lack of regulation or PMK has not discussed the revaluation of assets for accounting purposes. Therefore, it makes actually legitimate for companies to revalue fixed assets with purpose of accounting and later will not be taxed. The existence of a supporting statement from the General Provisions Act and Tax Procedure Article 28 Paragraph 7 makes 
it also true if the revaluation of land for the purpose of accounting is not subject to being taxed. In that regulation explanation there is a statement, namely:

"Thus, bookkeeping must be carried out in a way or system that commonly used in

Indonesia, for example based on Financial Accounting Standards, except tax laws and regulations determine otherwise."

Even though in this study does not discuss about bookkeeping, but this is like an implied rule in general which states that if the tax regulations do not regulate it so it must follow the applicable accounting rules, which in this case the company revalues for accounting purposes in overcoming the problem even this PSAK 16 allows companies to choose a cost model or revaluation model to be used in their company's accounting policies. So, it is legitimate if the company wants to do the revaluation because it is permitted under PSAK and there are no tax regulations that regulate it.

As for the fixed assets revalued by the company it is already safe. Land is an asset that is not depreciated, so if there is a revaluation or not it will not change the value of the tax produced. Basically land does not affect the amount of the tax except when the land is sold or transferred to another person. Based on all of the facts, the author also supports the argument of the taxpayer or company that the fixed asset (land) revaluation carried out for accounting purposes should not be taxed because there is no clear regulation, statements or facts that clearly support this matter. The thoughts of the tax authorities make them not courageous enough to take the risks, so naturally they choose to follow the existing written regulations.

\section{CONCLUSION}

Based on the research that has been done, it can be concluded that the lack of regulations or the absence of an official adjustments regarding the regulations that discuss about the revaluation of fixed assets in accounting and taxation, make tax consultants and taxpayers experience confusion in performing their tax obligation. When the company revalues the fixed asset (land) for accounting purposes, the company feels safe and has not thought of being taxed. It can happen because based on accounting regulations or PSAK 16 it is permissible to use revaluation model. The revalued assets (land) is non-depreciable asset and has no effect on taxation. The tax regulations itself do not regulate and discuss clearly regarding the revaluation of fixed assets in accordance to PSAK 16 if it will be taxed or not. But the activity turned out to be taxable by tax authorities because they are do not dare to take risk and always followed the existing regulations about revaluation of fixed assets even it is not talked or discussed in the regulations. This is very detrimental because it requires companies to pay more taxes, companies will feel unfairnedd and keep trying to find justice by holding on their arguments. And in another case, when other companies brought this case to the court with same conditions, that they do the revaluation for accounting purposes, the panel of judges at the court agreed with the companies argument and finally make the companies not being taxed. So, this is really confusing for taxpayers, companies, tax consultant and also the court because there are no definite rules about it. On other hand there are companies that have to pay more taxes and in other hand they do not have to pay more taxes on the revaluation of land asset.

As long as there is clear regulation, taxpayer will definitely follow it and will never be negligent and will pay taxes on these activities. This lack of regulations must be a focus for the Directorate General of Taxes (DGT) and must quickly consider to revise the exixting regulations since this year 2020, we are sure that many companies will consider to revalue their assets in order to have a fair and improved financial position and performance during the pandemic crisis. 
The limitation of this study: the focus of this study is only on the implications about the imposition of final income tax of $10 \%$ on the revaluation of fixed asset (land)in which the aim of the revaluation is not for tax purpose but to make the financial statement look more reasonable or fair (accounting purpose). This problem occurs to PT. X, a new company. PT. $\mathrm{X}$ is in the automotive industry selling motorcycle. The financial statement of PT. X shows a negative equity and their only solution to make it positive is to revalue their fixed asset (land). The main object of this research is the revaluation of fixed asset (land)

\section{Recommendation}

Based on the research that has been done, there are a suggestions to be conveyed by the author to parties who have the authority to make regulations in taxation. The tax regulator must always try to be able to update or revise the tax regulations with changes and revisions made by standards of accounting or SAK. Differences between accounting standards and tax regulations will always exist. This is because accounting objectives and taxation objectives are different. In addition, the principles of accounting standards and tax regulations are also different. Even though the difference between SAK and the tax regulations will never be eliminated, the regulators can take some action to minimize the difference between the current SAK (General SAK \& ETAP) and the tax regulations. The establishment of a special department precisely on March 13, 2014, namely the Tax Accountant Compartment by the Indonesian Accountants Association is an effort carried out by the authorities related to accounting standards and the Directorate General of Taxes (DGT) to make efforts to minimize negative impacts or harms both taxpayers and the state in terms of securing state revenues. However, it is assumed that the Tax Accountant Compartment has not been running optimally, since this tax imposition problem on revaluation of fixed assets is still not in harmony between the rules and the practices.

Revaluation referred to PSAK 16 concerning how the tax treatment for these activities has not been regulated at all in the existing PMK. So to make a legal certainty for taxpayers or companies, it is needed to do an update or revision to the existing PMK regarding the revaluation. The updates or revisions to the appropriate regulations regarding the revaluation can be discussed and adjusted by the Directorate General of Taxes (DGT) itself. Clarifying matters that have not been regulated in tax regulations is a homework that must be immediately resolved by the Director General of Taxes, so it can provide legal certainty and not give negative impact to the taxpayer in the future.

The year 2020 will be a good starting point to have the existing tax regulations on revaluations of fixed assets be revised. This year, many companies have suffered due to pandemic crisis. We can observe that at the end of the year there will be many companies with negative equity. And to make the financial position fair and attractive, one of the options is to revalue the existing fixed assets the company have but the revaluation will be for accounting purposes only. Therefore, if the rules and regulations about this assessment is clear, then it will help the company to survive. However, if the rules and regulations is not clear it will only confuse the taxpayers later and will put the company in a very dangerous position.

\section{REFERENCES}

Baridwan, Z. (1995). Intermediate accounting. Yogyakarta: BPFE.

Chilisa, B. (2011). Indigenous research methodologies. Thousand Oaks: Sage.

Creswell, J. W. (1994). Research design qualitative and quantitative approaches. Thousand Oaks, CA: SAGE Publications. 
Creswell, J. W. (2013). Qualitative inquiry \& research design: Choosing among five approaches. Los Angeles: Sage.

Directorate general of taxes of Republic Indonesia.(2004). Buku Informasi Perpajakan. Jakarta: Directorate General of Taxes of Republic Indonesia.

Djajadiningrat, S. I. (2003). Dasar-dasar perpajakan. Jakarta: Penerbit Salemba Empat.

Faruq.(2011). Harmonisasi peraturan menteri keuangan tentang revaluasi aktiva tetap tahun 2008 dengan pernyataan standar keuangan. Depok: Fakultas Ilmu Sosial dan Ilmu Politik, Universitas Indonesia.

Hadi, S. (2005). Aplikasi statistika dan metode penelitian untuk administrasi dan manajemen. Bandung: Dewa Ruchi.

Harahap, S. S. (1994). Akuntansi aktiva tetap (Akuntansi pajak, revaluasi leasing). Jakarta: Raja Grafindo Persada.

Hutagaol, J. (2007). Perpajakan isu-isu kontemporer. Jakarta: Graha Ilmu.

Ikatan Akuntansi Indonesia. (1998). Pernyataan standar akuntansi keuangan (PSAK) No 47: akuntansi tanah. Jakarta: IAI.

Ikatan Akuntansi Indonesia. (2011). Pernyataan standar akuntansi keuangan (PSAK) No 16: aset tetap. Jakarta: IAI.

Johannes, F. (2015, December 10). What the impact of fixed asset revaluation: accounting vs tax. Retrieved November 15, 2018, from https://www.linkedin.com/pulse/what-impactfixed-asset-revaluation-accounting-vs-tax-fransiskus

Kieso, D. E., Weygandt, J. J., \& Warfield, T. D. (2018). Intermediate accounting. Hoboken, NJ: Wiley.

Madian, M. (2016). Perbedaan revaluasi aset tetap menurut akuntansi dan perpajakan. Retrieved December 26, 2018, from http://www.jtanzilco.com/blog/detail/525/slug/perbedaan-revaluasi-aset-tetap-menurutakuntansi-dan-perpajakan

Maulita, D., \& Tania, I. (2018). Pengaruh debt to equity ratio (DER), debt to asset ratio (DAR), dan long term debt to equity ratio (LDER) terhadap profitabilitas. Jurnal Akuntansi : Kajian Ilmiah Akuntansi (JAK), 5(2), 132. doi:10.30656/jak.v5i2.669

Missonier-Piera, F. (2007). Motives for fixed asset revaluation: An empirical analysis with Swiss data. Perancis: ESSEC - Business School.

Neuman, L. W. (2007). Basic of social reasearch: Qualitative and quantitative approaches. Boston: Pearson Education Inc.

Prasetyo, B., \&Jannah, L. M. (2008). Metode penelitian kuantitatif: Teori dan aplikasi, Jakarta: PT Raja Grafindo Persada.

Saputra, Ardiantha. (2005). Analisis perencanaan pajak melalui revaluasi aset tetap dan penghitungan besarnya pajak terhutand wajib pajak badan. Bandung: Universitas Widyatama

Schindler, P. S., \& Cooper, D. R. (2008). Business research methods. New York, NY: McGraw-Hill/Irwin.

Sukardi. (2008). Metodologi penelitian pendidikan, kompetensi dan praktiknya. Jakarta : PT. BumiAksara.

The Minister of Finance of Republic Indonesia. (2008). Peraturan Menteri Keuangan Republik Indonesia Nomor 79/PMK.03/2008 tentang penilaian kembali aktiva tetap perusahaan untuk tujuan perpajakan. Retrieved November, 2018, from https://www.ortax.org/ortax/?mod=aturan\&page=show\&id=15899

The Secretariat of Republic Indonesia. (2007). Undang-undang Republik Indonesia No. 28 Tahun 2007 tentang perubahan ketiga atas undang-undang nomor 6 Tahun 1983 tentang ketentuan umum dan tata cara perpajakan. Retrieved November, 2018, from http://www.dpr.go.id/dokjdih/document/uu/UU_2007_28.pdf 
Trisnawati, E. (2005). Perbedaan antara kebijakan akuntansi dan perpajakan dalam aktiva tetap. Jakarta: Fakultas Ekonomi Universitas Tarumanegara.

Waluyo. (2011). Perpajakan Indonesia. Jakarta: Salemba Empat.

Warren, C. S., Reeve, J. M., \& Fees, P. E. (2006). Accounting. Jakarta: Salemba Empat.

Wendy, D. (2018). Data AISI distributor motor untuk tahun 2017. Retrieved November 25, 2018. From Motor Blog: https://motorbloginfo.wordpress.com/2018/01/10/data-aisidistribusi-motor-untuk-tahun-2017

\section{APPENDICES \\ LIST OF QUESTIONS}

To Company:

1. PT. X is a company engaged in what field?

2. How long has PT $\mathrm{X}$ been in operation?

3. Are there any problems related to net worth or net worth that have negative values, for example, that the company experienced in the previous year?

4. If so, what was the reason that the company's net worth was negative in the previous year?

5. How did the company handle this?

Oh..So revaluation of fixed assets is one of the methods used?

6. If the company carries out a revaluation as one of the methods, what fixed assets does the company choose for the revaluation?

7. When determining what fixed assets to be revalued, does the company consider the imposition of a final tax of $10 \%$ on the revaluation difference, as stated in PMK 79 ?

8. After conducting the revalue, are there any other problems that actually arise related to taxation (during the tax audit)?

9. If there is how did the company react? How did the company face the problem?

\section{Tax Consultant:}

1. Are the regulations in accounting and taxation aligned or in line with each other so far?

2. And when discussing revaluation, what kind of revaluation is discussed in the accounting and taxation regulations?

3. Are there any differences found in the two regulations that are not in line?

4. Is it true that there are differences written in the two regulations regarding the purpose of conducting the revaluation?

5. Given these differences in objectives, if the revaluation is carried out for accounting purposes, will it still be subject to final tax of $10 \%$ or not? Because in the tax regulations it is written that the revaluation carried out only for tax purposes will be subject to a final tax of $10 \%$.

6. If you focus on the revaluation of land based on tax regulations, is there anyone who has discussed in detail the land assets in Indonesia if they are revalued, they will be subject to a final tax of $10 \%$ ? Because in the regulation it is written "All tangible fixed assets excluding land, which are located or located in Indonesia, are owned, and are used to obtain, collect and maintain income which is a tax object

7. What are the facts in the field carried out by practitioners of taxation if they are in a condition where revaluation, especially land, is carried out not for tax purposes but for accounting purposes? 